\title{
A Study on the Mixture Ratio of Pumice Powder Concrete on the Concrete Pavement and the Construction of Building
}

\author{
Abdulrezzak BAKIȘ ${ }^{1}$, Ercan IŞIK ${ }^{2}$, Alev Akıllı EL ${ }^{3}$, Mustafa ÜLKER ${ }^{4}$ \\ ${ }^{I}$ (Bitlis Eren University, Faculty of Engineering and Architecture, Civil Engineering Department, Turkey) \\ ${ }^{2}$ (Bitlis Eren University, Faculty of Engineering and Architecture, Civil Engineering Department, Turkey) \\ ${ }^{3}$ (Bitlis Eren University, Vocational School of Technical Sciences, Construction Department, Turkey) \\ ${ }^{4}$ (Bitlis Eren University, Vocational School of Technical Sciences, Construction Department, Turkey)
}

\begin{abstract}
Pumices which have substantially the reserve in the region of Bitlis and are known with the name of "bims" are the robust extrusive rocks against the aerated, spongy, physical and chemical factors which occurred when the extrusive lavas which occurred with the explosion of crater Nemrut in the region in the past expanded and cooled. As the pumice with the pore substantially at the macro and micro sizes has a very low compressive strength, its usage field has been restricted in the sector of construction, and it is mainly used in the construction of wall and par get in the purpose of insulation. As the pumice aggregate has a very low compressive strength, it isn't used as the construction concrete in the bearing parts of buildings. This is why the pumice aggregate which is used in the concrete has the high-amount gaps. The compressive and bending strength of concrete which will be done by grinding the bulky pumice aggregate and making it powder can be increased. The concrete which was done in this way was named as Pumice Powder Concrete (PPC). This study was prepared in order to provide the common usage of PPC in the sector of construction, to contribute to the regional and national economy with widening the pumice's usage fields in this way. The mixture ratios at the different water/binder ratios of Pumice Powder Concrete (PPC) were obtained for the rigid pavement and the construction of building in this study. PPC mixtures were done in two ways as the fibrous and non-fibrous ones. In the study, the mixture ratios were done as 0.20-0.30-0.40 and 0.50 of the fibrous and non-fibrous PPC mixtures' water/binder ratios, and they were shown on the tables.
\end{abstract}

Keywords: Pumice, Reactive Powder Concrete, Pumice Powder Concrete, Concrete mixture ratios

\section{Introduction}

Bitlis has an important potential especially in terms of pumice fields with the province's geological structure and as it was established on an extrusive area. The aforementioned fields are in Bitlis' district, Tatvan, and there are well-quality pumice fields [1]. According to the data from The General Directorate of Mining Affairs, there are 45 pumice fields in total which have actively worked in Bitlis since 2015. The necessary attempts should be taken to give importance efficiently to the pumice mining in Van and Bitlis, and the investors should be incited. As the usage of pumice increases, its advantage will substantially be great specifically for the regional economy and generally to the national economy [2]. The pumice is especially used in the generation of trass cement. This kind of extrusive rock is said as puzzolana. Those which are naturally found and obtained among the pozzolanas are named as trass. Our country has an extrusive rock field of $155000 \mathrm{~km}^{2}$ [3]. According to the formal data of a country which is the richest for the pumice reserve, the first one is USA and the second one is Turkey [4]. The pumice sources which are determined over the world are nearly 18 billion $\mathrm{m}^{3}$. The pumice reserve in Turkey is nearly 2.8 billion $\mathrm{m}^{3}$. Accordingly, the pumice sources in Turkey correspond nearly to $15.8 \%$ of the pumice sources over the world. Italy, Greece, Iran, Syria, Chile and Saudi Arabia follow USA and Turkey in terms of the pumice reserve [5]. In this study a new concrete type that the pumice powder was used in it was developed in consideration with the mixture ratios of Reactive Powder Concrete (RPC). This new concrete was named as Pumice Powder Concrete (PPC).

The Reactive Powder Concrete (RPC) which has the highest compressive and bending strength in the concrete types is an ultra-high-performed concrete which is done with the implementation of specific cures generally with cement, silica fume, quartz sand, quartz powder, steel fiber, water and super plasticizer [6]. There haven't been seen any PPC generation which has been done with the use of pumice powder in consideration with Reactive Powder Concrete (RPC) in the literature searches. This study was prepared in order to provide the common usage of PPC in the construction sector, to contribute to the regional and national economy by widening the usage field of pumice in this way. In this study, the mixture ratios in the different water/binder ratios of Pumice Powder Concrete (PPC) were reviewed for the concrete pavement and the construction of building.

It is demanded that the water/binder ratio isn't more than $55 \%$ in the production of structure concrete [7]. It is demanded that the maximum water/binder ratio is $0.40-0.45$ in the specifications for the proportioning 
of rigid pavement on the concrete roads [8]. In the study, mixture ratios were obtained with $0.20-0.30-0.40$ and 0.50 water/binder ratios of PPC mixtures. PPC mixtures were done in two ways as the fibrous and non-fibrous ones. The construction of the lightweight and high-strength rigid pavements and buildings is possible with the mixture ratios which were done in this way. It is demanded that the study will help to the employees in the rigid pavement and building construction sector.

\section{Material And Method}

CEM I-II 42.5 R type cement is used in the generation of Pumice Powder Concrete (PPC). The city water supply should be used at a quality that it would be drunk as concrete mixture water. It is possible to use the grey-colored acidic pumice as the pumice aggregate. The samples of acidic pumice are seen on Figure 2.1.

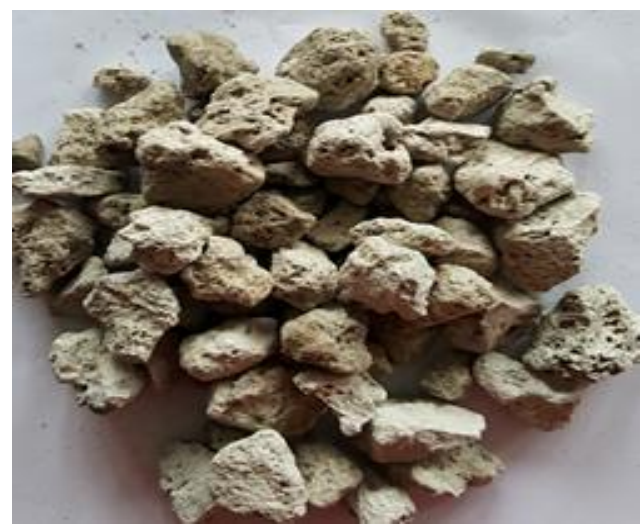

Fig. 2.1. Acidic pumice

The pumices which are provided from the mine in the generation of PPC should be grinded at the range of 0.1-0.6 and should be done as powder. The current pumice powders which are naturally seen in the pumice mines in the generation of PPC and have the range of grain diameter that was determined can be also used. The image of acidic pumice which was obtained after it was grinded in the grinding machine was seen on Figure 2.2.

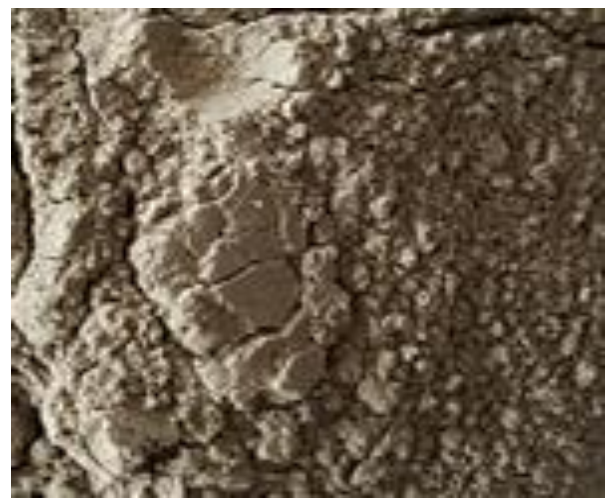

Fig. 2.2. Acidic pumice powder

The silica fume material which was used in the generation of PPC is seen on Figure 2.3.

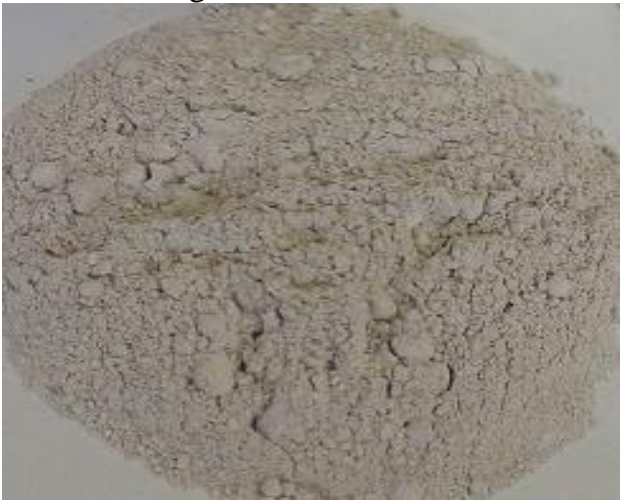

Fig. 2.3. Silica fume 
The silica fume grains which were used in the generation of PPC fill in the gaps by putting into the bulkier cement grains, and it contributes to the manner that the concrete gets the more resisting form by reacting during the hydration. The steel fibers to be used in the fibrous PPC production would be a crooked or noncrooked one at the length of $30 \mathrm{~mm}$, with $0.55 \mathrm{~mm}$ diameter or at the nearby sizes. The industrial-waste steel fibers would be used in the production. The hooked and flat steel fibers are seen on Figure 2.4.

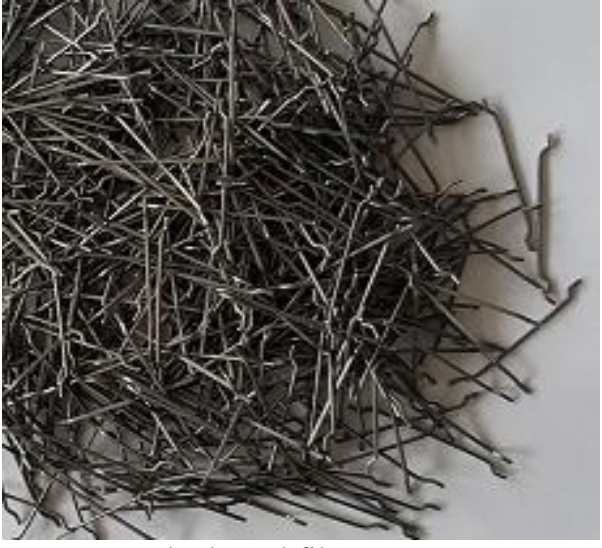

Hooked steel fibers

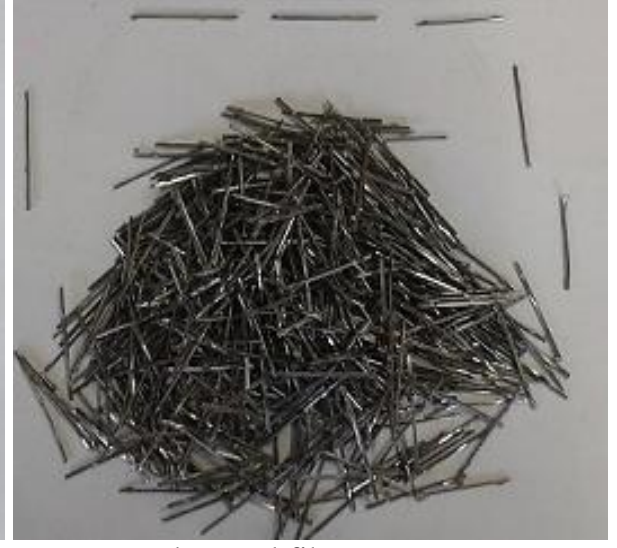

Flat steel fibers

Fig. 2.4. Steel fibers

The other materials' amount is proportioned in terms of weight by the cement's amount which is used in RPC's. The other materials are sliced into the ratio's percentage by weight according to the cement's amount, and the mixture is done. RPC's are generally divided as RPC200 and RPC800. Generally, the cement amount which is used in the production of RPC is at the range of $900-1000 \mathrm{~kg} / \mathrm{m} 3$, the cement amount which is used in 1 m3 RPB200 is the average $950 \mathrm{~kg}$, and the cement amount which is used in $1 \mathrm{~m} 3 \mathrm{RPB} 800$ is the average $980 \mathrm{~kg}$ [6]. There isn't any domestic and foreign standard for the reactive powder concretes' mixture design. The different mixture theories were used to rate the grainy materials in the mixture in a way to make a tight structure [9]. These theories arose from Mooney's suspension viscosity model $[9,10]$. The mixtures which are generally used from the different mixture ratios that occur with the use of Mooney's model are seen at Table 2.1 [11].

Table 2.1. Mixture ratios of typical RPC200 and RPC800 concretes according to cement [11]

\begin{tabular}{|l|c|c|c|c|c|c|}
\hline & \multicolumn{4}{|c|}{ RPC200 } & \multicolumn{2}{c|}{ RPC800 } \\
\hline Materials & \multicolumn{2}{|c|}{ Non-Fibrous } & \multicolumn{2}{|c|}{ Fibrous } & $\begin{array}{c}\text { Silica } \\
\text { Aggregates }\end{array}$ & $\begin{array}{c}\text { Steel } \\
\text { Aggregates }\end{array}$ \\
\hline Portland Cement & 1 & 1 & 1 & 1 & 1 & 1 \\
\hline Silica Fume & 0.25 & 0.23 & 0.25 & 0.23 & 0.23 & 0.23 \\
\hline Sand (150-600 $\mu \mathrm{m})$ & 1.1 & 1.1 & 1.1 & 1.1 & 0.5 & - \\
\hline $\begin{array}{l}\text { Crushed Quartz } \\
\left(\mathrm{d}_{\text {s0 }} \text { 10 } \mu \mathrm{m}\right)\end{array}$ & - & 0.39 & - & 0.39 & 0.39 & 0.39 \\
\hline Super plasticizer & 0.016 & 0.019 & 0.016 & 0.019 & 0.019 & 0.019 \\
\hline Steel Fiber (L =12.mm) & - & - & 0.175 & 0.175 & - & - \\
\hline Steel Fiber (L=3.mm) & - & - & - & - & 0.63 & 0.63 \\
\hline $\begin{array}{l}\text { Steel aggregates } \\
(<800 \mu \mathrm{m})\end{array}$ & - & - & - & - & - & 1.49 \\
\hline Water & 0.15 & 0.17 & 0.17 & 0.19 & 0.19 & 0.19 \\
\hline
\end{tabular}

In this study, RPC200 values were considered to make all of the fibrous and non-fibrous Pumice Powder Concrete (PPC) mixture ratios.

\section{The Generation Of Pumice Powder Concrete Mixture Ratios \\ III.a. The Ideal Non-Fibrous Pumice Powder Concrete Mixture Ratios}

At Table 2.1, in consideration with the mixture ratios which are given in one unit, the formula between the total mixture weight and the cement amount is formulated as the following in order that it provides convenience in the calculations $[6,11]$ :

$1 \mathrm{~m}^{3}$ RPC Mixture Weight $(\mathrm{kg})=2.516 \times 1 \mathrm{~m}^{3}$ RPC Cement's Amount $(\mathrm{kg})$ 
If $1 \mathrm{~m}^{3} \mathrm{RPC}$ mixture weight is $2400 \mathrm{~kg}$, the cement's amount to be used in the mixture will be nearly $954 \mathrm{~kg}$ as a result of 2400/2.516 ratio from The Formula 3.1. After the cement's amount is found as $954 \mathrm{~kg}$, the other materials' amount to be used in the mixture is determined by the ratios of following mixture [6,11]. At Table 2.1, in consideration with the mixture ratios which are given in one unit, the mixture is done in the generation of non-fibrous and non-powder RPC as preparing the silica fume at $25 \%$ of the cement's amount, the sand content at $110 \%$ of the cement's amount, the super plasticizer at $1.6 \%$ of the cement's amount, the mixing water at $15 \%$ of the cement's amount $[6,11]$. These values were used to provide the ideal PPC mixture ratio. According to $954 \mathrm{~kg}$ cement's amount to used in $1 \mathrm{~m}^{3}$ mixture, the ideal non-fibrous Pumice Powder Concrete (PPC) mixture ratio was shown at Table 3.1. The water/binder ratio of the ideal non-fibrous PPC samples is 0.12 and the silica fume/cement's ratio is 0.25 .

Table 3.1. The ideal non-fibrous PPC mixture ratios

\begin{tabular}{|l|c|}
\hline Materials & Quantity $\left(\mathbf{k g} / \mathbf{m}^{\mathbf{3}}\right)$ \\
\hline Portland Cement & 954 \\
\hline Silica Fume & 238 \\
\hline Pumice $(0,15-0,6 \mathrm{~mm})$ & 1050 \\
\hline Super plasticizer & 15 \\
\hline Water & 143 \\
\hline TOTAL & 2400 \\
\hline
\end{tabular}

\section{III.B. The Ideal Fibrous Pumice Powder Concrete (PPC) Mixture Ratios}

At Table 2.1, in consideration with the mixture ratios which are given in one unit, the formula between the total mixture weight and the cement amount is formulated as the following in order that it provides convenience in the calculations $[6,11]$ :

$1 \mathrm{~m}^{3}$ RPC Mixture Weight $(\mathrm{kg})=2.711 \times 1 \mathrm{~m}^{3}$ RPC Cement's Amount $(\mathrm{kg})$

If $1 \mathrm{~m}^{3} \mathrm{RPC}$ mixture weight is $2400 \mathrm{~kg}$, the cement's amount to be used in this mixture will be nearly $885 \mathrm{~kg}$ as a result of 2400/2.711 ratio from The Formula 3.2. After the cement's amount is found as $885 \mathrm{~kg}$, the other materials' amount to be used in the mixture is determined by the following mixture ratios [6, 11]. At Table 2.1, in consideration with the mixture ratios which are given in one unit, the mixture is done in the generation of fibrous-powder RPC by preparing the silica fume at $25 \%$ of the cement's amount, the sand content at $110 \%$ of the cement's amount, the super plasticizer at $1.6 \%$ of the cement's amount, the mixing water at $17 \%$ of the cement's amount and the steel fibers at $17.5 \%$ of the cement's amount $[6,11]$. These values were used to reveal the ideal fibrous Pumice Powder Concrete (PPC) mixture ratios. The ideal fibrous Pumice Reactive Powder Concrete (PPC) by $885 \mathrm{~kg}$ cement's amount to be used in $1 \mathrm{~m}^{3}$ mixture is shown at Table 3.2. The water /binder ratio of the ideal fibrous PPC samples is 0.13 and the silica fume/cement's ratio is 0.25 .

Table 3.2. The ideal fibrous PPC mixture ratios

\begin{tabular}{|l|c|}
\hline Materials & Quantity $\left(\mathbf{k g} / \mathbf{m}^{\mathbf{3}}\right)$ \\
\hline Portland Cement & 885 \\
\hline Silica Fume & 221 \\
\hline Pumice $(0,15-0,6 \mathrm{~mm})$ & 975 \\
\hline Super plasticizer & 14 \\
\hline Steel Fiber & 155 \\
\hline Water & 150 \\
\hline TOTAL & 2400 \\
\hline
\end{tabular}

\section{III.C. The Non-Fibrous Pumice Powder Concrete (Non-Fibrous PPC) Mixture Ratios}

In this study, the new mixture ratios were provided in a way that the non- fibrous Pumice Powder Concretes' (PPC) water/binder ratio would be $0.20-0.30-0.40$ and 0.50 . 
The mixture is done for the generation of non-fibrous pumice powder concrete (Non-fibrous PPC20) which its water /binder ratio is 0.20 by preparing the silica fume at $25 \%$ of cement's amount, the sand content at $100 \%$ of cement's amount, the super plasticizer at $1.6 \%$ of cement's amount, the mixing water at $25 \%$ of cement's amount in one unit. The non-fibrous-PPC20 mixture ratios are seen at Table 3.3. The non-fibrous PPC20 concrete's water/binder ratio is 0.20 and the silica fume/cement's ratio is 0.25 .

Table 3.3. Non-fibrous PPC 20 mixture ratios

\begin{tabular}{|l|c|}
\hline Materials & Quantity $\left(\mathbf{k g} / \mathbf{m}^{\mathbf{3}}\right)$ \\
\hline Portland Cement & 954 \\
\hline Silica Fume & 238 \\
\hline Pumice $(0,15-0,6 \mathrm{~mm})$ & 954 \\
\hline Super plasticizer & 15 \\
\hline Water & 239 \\
\hline TOTAL & 2400 \\
\hline
\end{tabular}

The mixture is done for the generation of Non-Fibrous Pumice Powder Concrete (Non-Fibrous PPC30) which its water /binder ratio is 0.30 by preparing the silica fume at $25 \%$ of cement's amount, the sand content at $87.5 \%$ of cement's amount, the super plasticizer at $1.6 \%$ of cement's amount, the mixing water at $37.5 \%$ of cement's amount in one unit. The Non-Fibrous-PPC30 mixture ratios are seen at Table 3.4. The non-fibrous PPC30 concrete's water/binder ratio is 0.30 and the silica fume/cement's ratio is 0.25 .

Table 3.4. Non-fibrous PPC 30 mixture ratios

\begin{tabular}{|l|c|}
\hline Materials & Quantity $\left(\mathbf{k g} / \mathbf{m}^{\mathbf{3}}\right)$ \\
\hline Portland Cement & 954 \\
\hline Silica Fume & 238 \\
\hline Pumice $(0,15-0,6 \mathrm{~mm})$ & 835 \\
\hline Super plasticizer & 15 \\
\hline Water & 358 \\
\hline TOTAL & 2400 \\
\hline
\end{tabular}

The mixture is done for the generation of non-fibrous pumice powder concrete (Non-fibrous PPC40) which its water /binder ratio is 0.40 by preparing the silica fume at $25 \%$ of cement's amount, the sand content at $75 \%$ of cement's amount, the super plasticizer at $1.6 \%$ of cement's amount, the mixing water at $50 \%$ of cement's amount in one unit. The Non-Fibrous-PPC40 mixture ratios are seen at Table 3.5. The non-fibrous PPC40 concrete's water/binder ratio is 0.40 and the silica fume/cement's ratio is 0.25 .

Table 3.5. Non-fibrous PPC40 mixture ratios

\begin{tabular}{|l|c|}
\hline Materials & Quantity $\left(\mathbf{k g} / \mathbf{m}^{\mathbf{3}}\right)$ \\
\hline Portland Cement & 954 \\
\hline Silica Fume & 238 \\
\hline Pumice $(0,15-0,6 \mathrm{~mm})$ & 716 \\
\hline Super plasticizer & 15 \\
\hline Water & 477 \\
\hline TOTAL & 2400 \\
\hline
\end{tabular}

The mixture is done for the generation of Non-Fibrous Pumice Powder Concrete (Non-Fibrous PPC50) which its water /binder ratio is 0.50 by preparing the silica fume at $25 \%$ of cement's amount, the sand content at $62.5 \%$ of cement's amount, the super plasticizer at $1.6 \%$ of cement's amount, the mixing water at $62.5 \%$ of 
cement's amount in one unit. The Non-Fibrous-PPC50 mixture ratios are seen at Table 3.6. The non-fibrous PPC50 concrete's water/binder ratio is 0.50 and the silica fume/cement's ratio is 0.25 .

Table 3.6. Non-fibrous PPC50 mixture ratios

\begin{tabular}{|l|c|}
\hline Materials & Quantity $\left(\mathbf{k g} / \mathbf{m}^{\mathbf{3}}\right)$ \\
\hline Portland Cement & 954 \\
\hline Silica Fume & 238 \\
\hline Pumice $(0,15-0,6 \mathrm{~mm})$ & 597 \\
\hline Super plasticizer & 15 \\
\hline Water & 596 \\
\hline TOTAL & 2400 \\
\hline
\end{tabular}

III.D. The Fibrous Pumice Powder Concrete (PPC) Mixture Ratios

In this study, the new mixture ratios were provided in a way that the fibrous Pumice Powder Concretes' (the fibrous PPC) water/binder ratio would be 0.20-0.30-0.40 and 0.50 .

The mixture is done for the generation of Fibrous Pumice Powder Concrete (Fibrous PPC20) which its water /binder ratio is 0.20 by preparing the silica fume at $25 \%$ of cement's amount, the sand content at $102 \%$ of cement's amount, the super plasticizer at $1.6 \%$ of cement's amount, the mixing water at $25 \%$ of cement's amount and the steel fibers at $17.5 \%$ of cement's amount in one unit. The Fibrous PPC20 mixture ratios are seen at Table 3.7. The Fibrous PPC20 concrete's water/binder ratio is 0.20 and the silica fume/cement's ratio is 0.25 .

Table 3.7. Fibrous PPC 20 mixture ratios

\begin{tabular}{|l|c|}
\hline Materials & Quantity $\left(\mathbf{k g} / \mathbf{m}^{\mathbf{3}}\right)$ \\
\hline Portland Cement & 885 \\
\hline Silica Fume & 221 \\
\hline Pumice $(0,15-0,6 \mathrm{~mm})$ & 904 \\
\hline Super plasticizer & 14 \\
\hline Steel Fiber & 155 \\
\hline Water & 221 \\
\hline TOTAL & 2400 \\
\hline
\end{tabular}

The mixture is done for the generation of Fibrous Pumice Powder Concrete (Fibrous PPC30) which its water /binder ratio is 0.30 by preparing the silica fume at $25 \%$ of cement's amount, the sand content at $89.5 \%$ of cement's amount, the super plasticizer at $1.6 \%$ of cement's amount, the mixing water at $37.5 \%$ of cement's amount and the steel fibers at $17.5 \%$ of cement's amount in one unit. The Fibrous PPC 30 mixture ratios are seen at Table 3.8. The Fibrous PPC30 concrete's water/binder ratio is 0.30 and the silica fume/cement's ratio is 0.25 .

Table 3.8. Fibrous PPC 30 mixture ratios

\begin{tabular}{|l|c|}
\hline Materials & Quantity $\left(\mathbf{k g} / \mathbf{m}^{\mathbf{3}}\right)$ \\
\hline Portland Cement & 885 \\
\hline Silica Fume & 221 \\
\hline Pumice $(0,15-0,6 \mathrm{~mm})$ & 793 \\
\hline Super plasticizer & 14 \\
\hline Steel Fiber & 155 \\
\hline Water & 332 \\
\hline TOTAL & 2400 \\
\hline
\end{tabular}

The mixture is done for the generation of Fibrous Pumice Powder Concrete (Fibrous PPC40) which its water /binder ratio is 0.40 by preparing the silica fume at $25 \%$ of cement's amount, the sand content at $77 \%$ of cement's amount, the super plasticizer at $1.6 \%$ of cement's amount, the mixing water at $50 \%$ of cement's 
amount and the steel fibers at $17.5 \%$ of cement's amount in one unit. The Fibrous PPC40 mixture ratios are seen at Table 3.9. The Fibrous PPC40 concrete's water/binder ratio is 0.40 and the silica fume/cement's ratio is 0.25 .

Table 3.9. Fibrous PPC40 mixture ratios

\begin{tabular}{|l|c|}
\hline Materials & Quantity $\left(\mathbf{k g} / \mathbf{m}^{\mathbf{3}}\right)$ \\
\hline Portland Cement & 885 \\
\hline Silica Fume & 221 \\
\hline Pumice $(0,15-0,6 \mathrm{~mm})$ & 682 \\
\hline Super plasticizer & 14 \\
\hline Steel Fiber & 155 \\
\hline Water & 443 \\
\hline TOTAL & 2400 \\
\hline
\end{tabular}

The mixture is done for the generation of Fibrous Pumice Powder Concrete (Fibrous PPC50) which its water /binder ratio is 0.50 by preparing the silica fume at $25 \%$ of cement's amount, the sand content at $64.5 \%$ of cement's amount, the super plasticizer at $1.6 \%$ of cement's amount, the mixing water at $62.5 \%$ of cement's amount and the steel fibers at $17.5 \%$ of cement's amount in one unit. The Fibrous PPC50 mixture ratios are seen at Table 3.10. The Fibrous PPC50 concrete's water/binder ratio is 0.50 and the silica fume/cement's ratio is 0.25 .

Table 3.10. Fibrous PPC50 mixture ratios

\begin{tabular}{|l|c|}
\hline Materials & Quantity $\left(\mathbf{k g} / \mathbf{m}^{\mathbf{3}}\right)$ \\
\hline Portland Cement & 885 \\
\hline Silica Fume & 221 \\
\hline Pumice $(0,15-0,6 \mathrm{~mm})$ & 572 \\
\hline Super plasticizer & 14 \\
\hline Steel Fiber & 155 \\
\hline Water & 553 \\
\hline TOTAL & 2400 \\
\hline
\end{tabular}

\section{Conclusions}

The following results were obtained in the study:

- The silica fume/cement's ratios of all fibrous and non-fibrous PPC's which were done in the study are 0.25 , the water/binder ratios are at the range of $0.20-0.30-0.40$ and 0.50 . As the maximum water/binder ratio of the concretes which were in the rigid pavement is $0.40-0.45$ in the specifications to rate the rigid pavement, the non-fibrous and fibrous PPC20, PPC30 and PPC40 concretes can be used in the construction of rigid pavements.

- As the maximum water/binder ratio of the concretes which were used in the buildings' bearing systems is 0.55, the non-fibrous and fibrous PPC20, PPC30, PPC40 and PPC50 concretes can be used in the construction of buildings.

- In the case that the fibrous PPC20, PPC30 and PPC40 concretes are used in the construction of rigid pavement, it isn't necessary to use the traditional equipment in the rigid pavement mixture. In the case that the fibrous PPC20, PPC30, PPC40 and PPC50 concretes are used in the construction of buildings, it isn't necessary to use the traditional equipment in the concrete mixture.

\section{Acknowledgments}

This study was supported by Scientific Research Projects Department of Bitlis Eren University, which project number BEBAP-2016.07.

[1]. http://www.mta.gov.tr (Access date: 28.05.2017)

\section{References}

[2]. Varol, O. O., Bitlis ve Van illerinde pomza madenciliğine genel bir bakış. Bilimsel Madencilik Dergisi, 55(3),2016, 27-34.

[3]. Ünsal, N., İnşaat Mühendisleri İçin Jeoloji. 2006, Alp Yayınevi, Ankara.

DOI: 10.9790/1684-1403068390 $\quad$ www.iosrjournals.org $\quad 89 \mid$ Page


[4]. Önem, Y., Sanayi Madenleri, 2000, Kozan Ofset Matbaa, Ankara,

[5]. Dinçer, İ., Orhan, A., Çoban, S. Pomza Araştırma ve Uygulama Merkezi Fizibilite Raporu.2015, Nevşehir.

[6]. Bakış, A., Rijit yol üstyapı inşasında reaktif pudra betonun (RPB) kullanılabilirliğinin araștırılması. Doktora Tezi, Atatürk Üniversitesi Fen Bilimleri Enstitüsü, 2015.

[7]. Bedirhanoğlu, I., Yapı malzemesi. beton tasarımı. http://www.dicle.edu.tr/a/idrisb/webtr/Yapi\%20Mlz/YM-5Beton.pdf (10.06.2015)

[8]. Tunç, A., Yol malzemeleri ve uygulamaları. 2.Baskı, Nobel Yayın Dağıtım.2007.

[9]. İpek, M., Reaktif pudra betonların mekanik davranışına katılaşma süresince uygulanan sıkıştırma basıncının etkileri.Doktora Tezi,Sakarya Üniversitesi Fen Bilimleri Enstitüsü, Sakarya. 2009.

[10]. Larrard, F.,Sedran, T., Optimization of ultra-high-performance concrete by the use of a packing model. Cement and Concrete Research, 24 (6), 1994, 997-1009.

[11]. Richard, P.,Cheyrezy, M., Composition of reactive powder concretes. Cement and Concrete Research, 25, 1995, 1501-1511. 